\title{
Faculty as a Barrier to Dismantling Racism in Social Work Education
}

\author{
Ebony N. Perez
}

\begin{abstract}
Facilitating learning around race and racism is often uncomfortable for faculty as well as students. The purpose of this qualitative case study was to investigate the experiences of undergraduate social work educators who teach about race and racism in social work programs. I employed a qualitative case study design to understand the lived experience of undergraduate social work educators who teach race specific content. I employed a combination of purposive sampling and snowballing methods to identify nine participants from the Southeast region of the United States. Utilizing a Critical Race Theory (CRT) framework to analyze interviews, several key findings emerged revealing faculty as barriers to facilitating learning around anti-racist content in the classroom. These findings were a) their own racial identity; b) insufficient formal preparation around race and racism; c) lack of faculty comfort with anti-racist content; and d) lack of skill in teaching anti-racist content. Recommendations include the implementation of scaffolded antiracist content throughout social work curricula that would be required by the Council on Social Work Education as part of the accreditation process.
\end{abstract}

Keywords: Critical Race Theory, social work, faculty, race, racism

Davis (2016) posited that for "far too long, race has been America's postponed grand challenge" (p. 397). Referencing the 12 Grand Challenges revealed in 2015, which do not specifically include race or racism, Davis (2016) highlights how race has "been put on the back burner" (p. 397) even within the self-proclaimed profession for social justice. Scholars note that teaching strategies are not only shaped by the faculty's personal beliefs and motivations but also by the departmental structure and the relationship with their colleagues (Brew \& Mantai, 2017; Love, 2019; Smith et al., 2017). The intersection of race and gender are relevant within social work education due to $61.1 \%$ of social work educators identifying as White, $17.6 \%$ identifying as African American/ Other Black, and 6.8\% identifying as Chicano/Puerto Rican/or Other Latino (CSWE, 2020). Additionally, 73\% of social work educators identify as female (CSWE 2020). The lack of culturally relevant skills within the social work profession begins with social work educators.

Social work education programs have no reason to be invested in critically attending to race as it would not serve the interests of Whites (Bell, 1980). There is little incentive to eradicate racism within social work education as it would require the system to work to dismantle the current power structure. The inclusion of diversity content in curricula typically does not mandate critical self-examination to prepare students for practice (Deepak et al., 2015). Lack of critical engagement of race is one way social work supports the persistence of racial disparities and inequities (Constance-Huggins, 2018; Ortiz \& Jani, 2010). The current structure of the social work profession is dominated by whiteness and women, particularly White women. Thus in line with Bell (1980), gains within the educational structure and industry of social work have only come about due to desired political and personal gains, primarily of White women, that were supported by social work

Ebony N. Perez, PhD, MSW, Assistant Professor, Department of Undergraduate Social Work, Saint Leo University, St. Leo, FL.

Copyright (C) 2021 Authors, Vol. 21 No. 2/3 (Summer 2021), 500-521, DOI: 10.18060/24178 (cc) BY This work is licensed under a Creative Commons Attribution 4.0 International License. 
praxis. The training ground for this colorblind approach has been and continues to be the social work classroom. The result is a persistent lack of cultural relevant content in social work education. The purpose of this qualitative case study was to investigate the experiences of undergraduate social work educators who teach about race and racism in social work programs.

\section{Literature Review}

Scholars argue it is possible for a college student to go through their academic career never having critically examined their own racial bias (DiAngelo, 2018; Love, 2019; Patton, 2016). Social work education is not exempt from this phenomenon. The literature suggests skin color impacts pedagogy when teaching about race and racism (Holland, 2015; Pittman, 2010, 2012). Holland's (2015) work specifically revealed whiteness of participants obstructed their ability to both understand and teach content around race. With social work educators being primarily White and female this creates a paradox within social education programs. Jeffery's (2005) work illuminates that although the profession mandates the benevolent treatment of society's "unfortunate" souls the day-to-day practices of social work education reproduce whiteness. She argues the "good" social worker, "the white liberal subject, has the presumed capacity and potential to be chameleon-like: to know, see, and adapt as is necessary to maintain dominance in the situation" (Jeffery, 2005, p. 411).

The current demographics of social work educators, along with race being part of diversity management, point to the continued likelihood of reproducing the status quo. Jeffery (2005) further asserts that "critiques of whiteness, whether implicit or explicit, call into question the desirable identity of oneself as a good person, a good and altruistic helping professional" (p. 412). Therefore, educators need a "coherent theory of race" to develop their understanding of persistent racial inequalities, historical structure of race, the historical impact of race on contemporary practices, and their positionality as well as a specific focus critiquing whiteness (Bonilla-Silva, 2018; Jeffery, 2005; Smith et al., 2017). Smith-Maddox and Solòrzano (2002) assert such an agenda is key to move towards social justice and racial equity.

Cultural competency and multiculturalism (CCM) comprise the existing conceptual framework for meeting the mandate to engage diversity and difference in social work education and eventual practice. This chosen model highlights micro-level change and is largely focused on exposure, cultural awareness, and attitude readjustment of social work students (Campbell, 2014; Constance-Huggins, 2012; Rahill et al., 2016). It allows for the development of cultural appreciation and recognition of clients (Constance-Huggins, 2012) as well as the realization that clients may possess a cultural wealth that is absent from the practitioner's purview. For all of its good, this micro-level approach is limited in its ability to make a significant impact when engaging race and racism (Campbell, 2014). Relying on socially constructed U.S. categories, CCM does little to promote anti-racist activism. Abrams and Moio (2009) challenged social work educators to engage in developing a more relevant model and work towards anti-racist pedagogy. Without these skills, social workers may misapply principles to become the "white savior" negating their culpability in 
maintaining contemporary racism (Matias \& Mackey, 2015). Therefore, when it comes to the analysis of race, racism, and anti-racism on a macro level, the conceptual framework of CCM are largely ineffective (Abrams \& Gibson, 2007; Rahill et al., 2016).

Additionally, this framework ignores the historical legacies of race and how differences were, and continue to be, used to justify inhumane policies and practices (Adams \& Zuniga, 2016; Deepak et al., 2015; Love, 2019). It does not consider the emotional toll of learning new knowledge associated with race, racism, and anti-racism as well as the emotional stamina required to engage in such work. Without attention to the emotional component of learning, students may become discouraged or fatigued and therefore cannot fully engage in dismantling whiteness (Matias \& Mackey, 2015; Rahill et al., 2016). The challenge to social work education has been how to effectively address racial inequality within social work pedagogy. In 2014, the National Association of Social Workers (NASW) issued an action brief where part of their recommendations was for social workers to "understand, study, analyze, and address the ways 'color-blind racism' has become the dominant ideology in our work, conversations, and institutions" (p. 2). Therefore, social work educators need to train social work students to "identify and interrupt color-blind ideology" (NASW, 2014, p. 2). Yet the Council on Social Work Education (CSWE) still has not centered race within the educational standards, thus hindering social work educators' participation in moving students towards more racially just practitioners.

\section{Critical Race Theory (CRT)}

Critical Race Theory (CRT) provided a framework to study the relationship between race, racism, and power within social work education. CRT was described by Delgado and Stefanic (2012) as an activist movement grounded in legal scholarship which seeks to understand the effects of race and racism on society and change society for the better. CRT challenges normative standards of Whiteness and provides insight into how race, racism, and power interact to maintain and support racial inequality. Additionally, CRT supports the view that race is socially constructed rather than a biological fact (Crenshaw, 1995; Delgado \& Stefanic, 2012). This theory promotes a structural approach to addressing social injustice in a diverse society that goes beyond the expansion of access to opportunities. CRT contends that race is a social construct that impedes every aspect of social life, it promotes social justice, employs intersectionality concepts, and seeks to provide a space for marginalized voices (Delgado \& Stefanic, 2012). Furthermore, CRT operates multidirectionally to acknowledge personal resistance and distress as well as promotes structural approaches to address racism.

In this study, CRT offered a unique opportunity for social work researchers and educators to explore and respond to the challenges of the prevailing multicultural framework used in social work curricular approaches. Multicultural approaches touted to advance cultural competency dominates the social work literature as social work education's response to the CSWE (2015) mandate to "engage in diversity and difference in practice" and "to advance human rights" (p. 7). The dominant position of social work 
has been one of celebrating diversity and confronting individuals instead of systematic change.

\section{Context}

Historically marked by chattel slavery, the southeast region of the U.S. remains distinct in its political, economic, and social landscape. This study was conducted during the 20182019 academic year when the United States saw a rise in race and gender police brutality, anti-immigrant rhetoric and policy, and increasingly overt racism. Additionally, the Southern Poverty Law Center (SPLC) reports a higher concentration of hate groups in the southeastern region of the United States (SPLC, 2018). One state in the region was the first to champion and pass the controversial Stand Your Ground Law. This offers a unique landscape to investigate how social work educators deliver substantive content, employ pedagogical approaches, and educational activities that provide learning opportunities for students around race and racism. For this study, a case is defined as BSW educators who teach a required designated diversity and/ or social justice course in the Southeast region of the U.S.

\section{Sample}

In this inquiry, I employed a qualitative case study design to understand the lived experience of undergraduate social work educators who teach race-specific content. I used purposive sampling method (Patton, 2015; Lincoln \& Guba, 1985; Shavers \& Moore, 2014) to select CSWE-accredited social work programs in the Southeast region of the U.S. and identified 9 participants. Inclusion criteria for study participants were to teach BSW courses at CSWE accredited institutions, and to teach the required diversity course which included specific content on race and racism in undergraduate social work programs. Although there are other non-required courses where race may be discussed, the selection of the required diversity course was based on the premise that racism would be highly likely to be discussed in the required diversity course.

I specifically looked for faculty who have taught courses that fit the diversity and social justice description set by CSWE and is required for all BSW students. Additionally, I used snowball sampling to assist in the identification of participants by asking those who responded if they knew other faculty who might be interested and met the inclusion criteria (Creswell, 2013; Patton, 2015; Shavers \& Moore, 2014). This technique helped increase the likelihood of adjuncts participating in the study. All of the adjuncts who participated in the study were obtained through snowball sampling. Exclusion criteria were master level social work educators (MSW) and doctoral level educators (DSW or Ph.D.), those who teach an integrated race-content course, and educators with less than three years of teaching experience.

Nine social work educators agreed to take part and share their experiences teaching about race, racism, and antiracist practice in social work education programs. Given the sensitive nature of the topic, great care has been taken to protect the identity of the study participants. Protecting the identity of the participants is particularly important because 
discussions of the persistent racism and anti-racism content in the U.S. are being met with both public and private backlash.

Participant selection was intentional and sought information-rich or thick descriptions of cases for in-depth study (Lincoln \& Guba, 1985; Patton, 2015). According to the CSWE 2016 annual statistical report on faculty, adjunct faculty comprise $52.9 \%$ of both full-time and part-time faculty (CSWE, 2017). Additionally, less than half (44.3\%) of all full-time faculty were tenured. Table 1 details the demographics of the participants in this study. One participant had an EdD as their highest degree, six had a Ph.D., and two had earned their MSW degrees. Continuing from left to right each participant self-assigned a pseudonym for this study. Next is the participant's self-identified gender category, labeled "Gender." As indicated in Table 1, seven participants identified as women, and two identified as men. Afterward is the category of "Race" where each participant selfidentified as well. Five of the participants held some type of social work licensure as indicated in the fifth column. Following the "Licensure" category is the total number of years of teaching experience indicated in the column marked, "Teaching." The seventh column titled "Teaching Diversity" indicates the number of years the participant has taught the requisite diversity course. The "Public, Private, or Religious Predominately White Institution (PWI)" column indicates the type of institution the participant currently teaches in. The "Full Time Appt Type" column shows that two out of the nine participants were contingent or adjunct faculty. Table 1 summarizes the demographic information of the study participants.

\section{Method}

\section{Sample}

Utilizing purposive sampling (Lincoln \& Guba, 1985; Patton, 2015; Shavers \& Moore, 2014) I identified participants who met the following criteria: BSW faculty who (a) teach/ have taught in the Southeast region of the U.S.; (b) teach/ have taught a social work program's required diversity and/or social justice course; (c) had three or more years of experience teaching about race and racism; (d) who had taught a required designated course a minimum of three times. Participants held either full-time or adjunct faculty status and were either non-tenured, tenure-track, or tenured faculty. Exclusion criteria for the study were those who only taught about race or racism when it is embedded in other courses, had taught about race and racism for less than three years, and were either MSW, DSW, or Ph.D. only level educators. 
Table 1. Participants Demographics

\begin{tabular}{|c|c|c|c|c|c|c|c|c|c|}
\hline$\#$ & Pseudonym & Degree & Sex & Race/Ethnicity & Licensure* & $\begin{array}{c}\text { Teaching } \\
\text { Experience } \\
\text { (years) }\end{array}$ & $\begin{array}{c}\text { Teaching } \\
\text { Diversity } \\
\text { Experience } \\
\text { (years) }\end{array}$ & $\begin{array}{c}\text { Public, Private, } \\
\text { or Religious } \\
\text { PWI* }\end{array}$ & $\begin{array}{c}\text { Full Time } \\
\text { Appointment } \\
\text { Type } \\
\end{array}$ \\
\hline 1 & CJ & EdD & Woman & White & LSW & 13 & 10 & Private & Tenure \\
\hline 2 & Cynthia & $\mathrm{PhD}$ & Woman & African American & None & $25+$ & $25+$ & Public & Tenure \\
\hline 3 & Doc & $\mathrm{PhD}$ & Woman & African American & LMSW & 18 & 3 & Religious & Tenure Track \\
\hline 4 & Isabel & $\mathrm{PhD}$ & Woman & White & LCSW & 5 & 4 & Public & Adjunct \\
\hline 5 & Michael & $\mathrm{PhD}$ & Man & White & LISW-S & 6 & 3 & Public & Tenure Track \\
\hline 6 & Niang & MSW & Man & Senegalese & None & 8 & 5 & Public & Non-Tenure Track \\
\hline 7 & Regal & $\mathrm{PhD}$ & Woman & Black/African American & None & 3 & 3 & Public & Tenure Track \\
\hline 8 & Taffy & $\mathrm{PhD}$ & Woman & White & None & 19 & 3 & Private & Tenure \\
\hline 9 & Wonder Woman & MSW & Woman & African American & LISW-S & 4 & 3 & Public/Religious & Adjunct \\
\hline
\end{tabular}




\section{Data Collection}

Guidelines set forth by the Institutional Review Board (IRB) were followed before collecting data. I provided all participants the Informed Consent document via email and verbally informed all participants they could withdraw from participation at any time before beginning data collection. I obtained their consent either in person or via electronic means (i.e., a combination of email and phone or videoconferencing).

I conducted three semi-structured interviews with participants. Table 2 shows a sample of standard interview questions asked during sessions. All interviews were digitally recorded and transcribed using TEMI, an audio to text transcription service. I also kept a research journal to reflect on my thoughts throughout the process. Initial interviews were more general in focus and ranged from 45 minutes to an hour. Subsequent interviews were 60-90 minutes and were to garner more in-depth insights. Ultimately, 27 interviews with an average of 61 minutes were obtained. These interviews focused on professional insights, both as a social worker and as an educator, as well as gathered data regarding the pedagogical strategies educators employed to develop students' understanding of the role of race and racism in contemporary U.S. society. I coded the data into themes utilizing the Council on Social Work Education Educational Policy and Accreditation Standards (EPAS) and the specific tenets of CRT relevant to this inquiry.

\section{Table 2. Sample Interview Questions}

\section{Interview 1: General Questions}

1. Tell me about yourself. (Probe: area of social work practice, teaching experience, etc.)

2. Why did you decide to pursue teaching in a BSW program and what are your motivations to continue?

3. What historical and societal messages have you received about your racial heritage? About others? Can you describe your racial heritage?

4. What messages have you received (from family, friends, school, work, etc.) about your racial heritage? What

5. What have some of your supports been in understanding the importance of race and racism in social work practice?

\section{Interview 2: Social work values with regards to race/racism}

1. Do you believe the social work profession works to eliminate oppressive barriers? Why or why not?

2. Tell me: what is it like helping students understand structural barriers to social goods and resources? (Probe: access to quality services, education, and maintaining voting rights).

3. What is the role of a social workers in addressing racism and how do you help students understand this role? (Probe: Do you feel there is a professional ethical duty to do so?)

\section{Interview 3: Experiences and strategies teaching race/racism (Knowledge/Skills)}

1. CSWE identifies race as one mechanism of oppression students need to understand, what are your thoughts about that? (Probe: Do you agree/disagree?, Why/ why not?, To what extent?)

2. As you see it, what skills do students need to be able to promote social justice before they enter the field? How do you help them gain those skills?

3. What have been major barriers in teaching about race and racism, either inside or outside of the classroom (Probe: Scholars note student resistance or lack of institutional support, what are your experiences?). 
Additionally, I collected course syllabi, PowerPoints, and assignment descriptions specific to race, racism, and anti-racism that the participants utilized in the classroom. I viewed these items as constructed within and through structural conditions, context, and ideologies, which is consistent with my epistemological stance of critical constructivism. Specifically, I regarded the language within these texts as reflective of larger power structures that simultaneously informed and limited the fields' current stance and content delivery on issues of race, racism, and anti-racism. CRT served as an avenue to highlight these larger structures by centralizing the endemic nature of racism. The inclusion of syllabi, PowerPoints, and assignment descriptions helped to frame how these courses have been conceptualized, delivered, the program mission and goals, explicit and implicit curricula, and assessment criteria. Qualitative content analysis provides the means to interpret contextual data through systematic coding and identification of themes that may allow me to increase my understanding of the dominant frame adopted in undergraduate social work education regarding race and racism.

\section{Data Analysis}

A pattern-coding procedure was utilized to bring structure and meaning to data and identify emergent themes and patterns (Patton, 2015; Saldaña, 2015). The first coding cycle began with open coding technique (Saldaña, 2015) to get a sense of what the participant is sharing relative to teaching race and racism in the classroom. In the second coding cycle, I utilized focused coding to analyze how participants discussed pedagogical strategies of any kind (Saldaña, 2015). Next, in the third level of coding I employed pattern matching using Dedoose to determine how findings aligned, or misaligned, with the tenets of CRT, as well as with competencies two: engage diversity and difference in practice and three: advance human rights and social, economic, and environmental justice presented by CSWE and the corresponding EPAS. Informed by CRT, I also analyzed institutional arrangements that either contributed to or limited the delivery of race, racism, and anti-racism content with particular attention given to those who have less power in social and institutional settings (e.g. adjuncts, tenure-track faculty, and People of Color).

Furthermore, the syllabi, assignment descriptions, and PowerPoints began with coding focused by the EPAS composition of knowledge, values, and skills to systematically identify patterns and themes within the data. This was helpful as these categories put forth through the EPAS shape and drive course content; programs must meet these standards to earn accreditation (CSWE, 2008, 2015). In the second phase of coding, I conducted a descriptive analysis and sorted codes into the specific categories of knowledge, values, and skills and then looked for patterns within each category (Patton, 2015; Saldaña, 2015).

Trustworthiness is a critical component of the qualitative research process (Creswell, 2013; Lincoln \& Guba, 1985). Lincoln and Guba (1985) suggested trustworthiness increases the overall value of a research study. Strategies to augment the quality of my analysis included (a) prolonged engagement with 3-5 interviews; (b) triangulation to situate my emergent findings within the literature; (c) creating an audit trail; (d) thick, rich descriptions; and (e) engaging in a reflexive process throughout to consistently identify areas where my positionality, lived experiences, and epistemologies are located within 
analysis (Creswell, 2013; Lincoln \& Guba, 1985; Patton, 2015). Employing multiple techniques increases the credibility, rigor, and trustworthiness of my research design (Amankwaa, 2016; Creswell, 2013; Lincoln \& Guba, 1985; Patton, 2015).

\section{Positionality}

Harding (1993) maintains that all human beliefs are socially situated, "including our best scientific beliefs" (p. 142). To put it another way, when researchers acknowledge their biases and the potential influence that may have on how they interpret the data, there is potential for more honest and truthful research to emerge. It is not possible to dismiss a person's experiences, perspectives, or knowledge in the analysis of data (Strauss \& Corbin, 1998). Criticalists seek to look for ways to make sure their lenses and biases don't overly impact various aspects of the study. Strauss and Corbin (1998) state this knowledge may be useful sources of data generation in itself. Likewise, Merriam (2009) insists there is a need for the use of critical self-reflection with regards to "assumptions, worldviews, biases, theoretical orientation, and relationship to the study that may affect the investigation" (p. 229). In this next section, I pull back the curtain on the foundation of my worldviews, assumptions, and biases.

I acknowledge and accept the fact that each interview is a co-constructed product between the interviewer and the interviewee, and no two interviews are going to garner the same information out of the same person because every interaction is different (Holstein \& Gubrium, 1995). I hold several salient identities through which I live. I occupy several social identities; I am a Christian, a daughter, and a sister, as well as a wife and mother. However, as a Black person living in the U.S., my entire life has been lived as an explicitly racialized being that intersects with those other identities. As a past social work student, current social work professional and educator my blackness allowed for me to frame this project through a lens absent of racial neutrality. My education as a master- level social work student was primarily void of any discussion of race or the impact of race on policy and practice. In my experience in the early 2000 s, the topic of race was regulated to a single course and was not explored in any other courses. It was not until my full-year placement in my second year of the program that I began to realize that many of the theories and techniques taught in the program did not accurately prepare me to think about or work with communities of color.

I am fully aware and in acknowledgment that the prevailing ideology of colorblindness is not only a fallacy, but it serves to reinforce racism and maintain the current system of oppression even as the mechanisms may change. Social work education and practice have served as co-conspirators in preserving the very racism and oppression it has vowed to dismantle. CRT notes that my voice is unique, my perspective is valuable, and the absence of my experience, and other People of Color, leaves us examining only part of the landscape. As a Black woman, I occupy an almost constant state of awareness and reflection as I situate and process events, interactions, responses, and other daily occurrences of the world about race, both mine and those around me. This decades-long, formalized, non-academic education provided the foundation and passion to engage in this work. 


\section{Key Findings}

Six of the nine competencies outlined by CSWE specifically discuss diversity as being a central component. Thus, social work educators bear the responsibility of implementing the program's curriculum in a way to prepare students to demonstrate the integration and application of the knowledge, values, skills, and cognitive and affective processes required to engage in anti-racist social work practice. Several key factors emerged from the analyses that contribute to faculty themselves being barriers to the effective delivery and facilitation of anti-racist content within social work programs. Those factors were a) their own racial identity; b) insufficient formal preparation around race and racism; c) lack of faculty comfort with anti-racist content; d) lack of skill in teaching anti-racist content.

\section{Faculty Racial Identity}

The racial identity of the faculty served as an element that shaped the classroom environment. Three White participants specifically attributed their own racial identity as a barrier or adding to the challenge of teaching about race and racism. CJ stated, "As a White person it's a challenge [to teach about race]." As a White female in a rural setting, CJ appeared almost apologetic throughout the interview process. While she never hesitated in answering the interview questions, she often made remarks such as "I am ashamed to say" or "I really try" throughout the interviews. At the end of the process, she commented that she felt "good about" being able to talk about race and racism in social work in "an open way."

Isabel echoed her feelings, "I think since I am White sometimes, I'm seen as not credible because I haven't experienced, or they think I haven't experienced racism. They don't know my story." Race was not a salient part of her identity growing up yet after a series of life events she began to discover how much race "really matters." She credits these series of discoveries for providing her with the motivation to begin and continue to "explicitly teach about race and racism in America." When asked to explain Isabel continued, "okay, so I am White right? No big deal. But in my life, I am the odd one out. Most of the people in my life are Black or Brown because my family no longer speaks to me because of race. Students don't and won't know that about me. It just sometimes makes it hard because I don't have the same experience as my family and friends with racism, but I do have a personal connection, so it impacts me."

Admittedly Michael's struggle was more internal as he openly acknowledged that he believed him being a "White dude" at the front of the room played a major role in the lack of challenges he received in class. Due to his relationship with a colleague he could see the difference in the response to both teaching the same content. Michael offered, "There are things that at the front of the room I need to say and it's just complicated because I have had a different lived experience. A colleague of mine is an African American woman. Her [students] are at times so skeptical that they openly challenged her authority, her expertise maybe. I have never had to deal with that." In like manner, Taffy also revealed, "I suppose one barrier in part is me teaching it. I don't know if that's my own discomfort with realizing that I'm teaching about something I can't say I've experienced." 
The racial identity of Black faculty also impacted the classroom experience. Doc approached the interview with wisdom that exposed her almost two decades of social work practice in a variety of social work settings working with youth. As a former practitioner in multiple states, she was able to compare her experiences as a practitioner across geographic locations to her time teaching in the rural southeast. From her accounts, facing race within the classroom as an African American female has been far more challenging than when in practice.

Likewise, Niang also expressed that his presence as a Black male faculty member at times negatively impacted the classroom when he taught about race and privilege. In his interview, he shared, "Oh I have been openly challenged in the classroom about racism and privilege. Most often by White students." WonderWoman1920 also disclosed that she too had been challenged by students in the classroom. "Sometimes they get quiet and disengage when you talk about racism," she shared, "however several times, especially early on, students would just come at me. Like, there is no such thing as White privilege and we don't have to worry about racism anymore. The first few times I was shocked they would talk to their professor like that but then I realized I represent what they are fighting to ignore."

\section{Insufficient Formal Preparation to Teach Race and Racism}

The singular feature identified by each participant was the need to seek out and craft their process of self-study around race, racism, and antiracist practice. Each participant noted there was information about race and racism situated in their educational content however no one found that content sufficiently prepared them for practice nor teaching. Three participants identified the starting point of their self-education was when they knew they would be assigned to teach the required diversity course. Taffy shared, "I saw how race played out in practice. How nurses treated patients differently and whatnot but that didn't mean I could teach it. So I figured I needed to learn. There's compilations of books... Takaki, bell hooks, Freire, and others. I taught myself while I taught [race and racism], and I picked out the stuff that made sense, and it was a lot for me." Likewise, for Regal, critical scholars were important for grounding her teaching about race and antiracist content. She shared:

Within social work education, material on race and racism was really meaningless and generic. I take my cues from Freire, bell hooks, and that's what helped me a lot. I started bringing that into my program and asking well what about the power dynamic around race?

Having taught in social work education for over 25 years Cynthia averred, "Ignoring race in social work education or practice is not new. You have to keep looking for ways to get students to even acknowledge it much less talk about it. And the universities and conferences don't help. You have to learn it for yourself. Books, articles, and if you're Black or Brown in America just living."

Cynthia continued: 
You know back when I started in school there was very little significant talk about race other than Black people being a problem. I remember talking to my professors and saying, "okay so we talk a bit about feminism, but what about Black women, not just women? What about all of the barriers for Black people in this country?" (Laughs) You know those professors looked at me and said, "Oh you're one of them." I was thinking if by them you mean thinking folk then, yes, I am (laughs louder). It was difficult to get any content about Black people incorporated into the curriculum. So, I read. I read Freire, and Lorde, and hooks, and many others.

\section{Lack of Faculty Comfort with Anti-racist Content}

When the conversations turned to experiences delivering race and racism content in the classroom participants noted that faculty should have some level of comfort around the topic in the classroom. Anti-racism is not an affable topic yet if faculty approach the topics of race and racism with apprehension the effect on the classroom can be detrimental to students' learning process around race. Seven of the nine participants specifically noted that either they have experienced this themselves or have witnessed colleagues fumble around concepts of racism and White supremacy.

Wonder Woman1920 placed responsibility on the educator to not be timid about broaching race and racism with students. She reasoned, "Faculty, adjunct or full-time, need to be able to talk about race. We need to know what our feelings are on issues and what are the hot buttons so we can help students work through them. Really so we can help our clients and our students."

Regal shared a conversation she had with a faculty member who was uncomfortable with the use of the term White supremacy being explicitly in the classroom. She described a conversation with a colleague:

This White colleague of mine was so uncomfortable with that word and I'm like, huh? You know, to me that was kind of alarming, but it shouldn't have been, I guess. But you know so you have a problem with the term White supremacy I know you ain't talking about it [in class]. I know this doesn't come up in your class at least not from you. You're not initiating this conversation about White supremacy because you're uncomfortable with it. And when it does come up what do you do?

Niang noted that "social work education programs don't prepare faculty or students to deal with racism, in or out of the classroom. So then how are social work faculty, especially White faculty, supposed to be comfortable with it? And then how do we expect them to teach it especially when White people don't usually even deal with race or racism." Similarly, Michael shared,

... as a White male I didn't really ever talk about race growing up. And there was no in-depth discussion of racism in my courses as a student. I was really nervous and I think about that first term teaching race and it was a disaster. But I wasn't comfortable with it even though I tried. I feel bad for those students. It definitely could've been much better. 


\section{Lack of Skill in Teaching Anti-racist Content}

As participants revealed, comfort level with White supremacy, racism, and race can hinder the learning environment. Yet they were vocal about the importance of needing to have the skill to discuss and facilitate learning explicitly focused on progressing students towards future anti-racist social work practice. Isabel stated, "race and privilege are difficult alone yet when you put them together it's like creating a pressure cooker situation. But it is so critical to being able to be a social worker. You have to know the areas you are privileged in or even how others may wrongfully perceive you as privileged. You need to know what to do with that."

Lack of faculty skill teaching anti-racist content was also identified as a challenge for both full-time and contingent faculty. CJ recounted a time when a last-minute change in faculty resulted in an adjunct teaching the required diversity course and negatively impacted the cohort. She recounted:

When a White student created tension in the classroom, neither the other students nor the faculty knew how to respond, and I was not made aware of the problem until late in the term. It ended up being really, really bad and I don't think anyone really learned much about race. If anything, I think the adjunct's silence made some students believe she agreed.

Regal shared that her first time teaching the diversity course was as a doctoral student. This led her to question how much the program truly valued the content in the course. She reflected,

I'm a doc student and I'm teaching the diversity class. So that makes me wonder, well, how much do ya'll really care about this class if you're letting someone who's never been formally trained to teach this class? And even like the same for like adjuncts. They don't have the support full-time faculty have so what happens to prepare them? What resources do they have to process all of this because I know how little we have as full-time faculty?

\section{Discussion}

Social work is guilty of actively maintaining racial disparities and inequities within its education structure despite the outward commitment to social justice. For example, some of the participants remarked on the Twelve Grand Challenges developed to "initiative to champion social progress powered by science. It's a call to action for social work researchers and practitioners" (Grand Challenges for Social Work, 2021, para. 1). For these participants, this effort does not amount to any more than the typical incremental changes, if any at all. Yet these grand challenges do not center nor critically engage the topic of race and racism within social work praxis and research. The initial lack of overt attention on race and racism within their initial call to action embraces a colorblind ideology (BonillaSilva, 2018) and ignores inequity even while trying to attend to social injustice (Kolivoski et al., 2014). The creators and supporters of the Twelve Grand Challenges have chosen to ignore the longevity of systemic racism and provides justification for avoiding the 
responsibility of challenging and dismantling racism within social work praxis (Bell, 1980; Kolivoski et al., 2014). Moreover, CSWE full endorsement of this initiative and the overt act of offering focused workshops and presentations at the Annual Program Meeting allows for the appearance of progressiveness without actually developing and supporting practitioners to be able to enact substantial social change (Bell, 1980; Bonilla-Silva, 2018).

The participants in this study, irrespective of race, contend that a deeper, more critical understanding of race and racism has been largely ignored in social work education and practice alike marginalizing race to a burden to bear by people of color, depleting our racial stamina to engage in ongoing education, self-awareness, and anti-racist practice. Study participants believed providing the opportunities to foster a critical self-awareness and selfregulation around is not only an accreditation task but a moral, professional obligation.

Throughout their commentary participants noted that it is critical to foster selfawareness of bias and give students the opportunity to practice processing their emotions around race and racism. The participants in this study noted that initiating the topic of race and discrimination was hard work and conversations about race, particularly in interracial spaces, are difficult and uncomfortable. Participants shared the shifting sociopolitical climate that has allowed once-covert bigoted ideologies to become the norm has made it more difficult in some cases to raise students' self-awareness. Essed (1991) stated students ignoring or denying racist acts can become a common strategy to deny the existence of racism in a society. The participants were ill-prepared through academic and professional channels to correct bigoted thoughts around race. Given the potential for intense emotion and friction around race and racism, it is understandable why people are eager to avoid such conversations. Albeit difficult, study participants maintained such conversations were crucial to developing students' self-awareness yet admitted to having to intentionally work on building those skills.

Within higher education, Patton (2016) argues that higher education is rooted in white supremacy and serves as a primary source in enforcing inequities, and continues to represent a complex relationship between race, property, and oppression. Jay (2003) asserts, "the teaching of transformative knowledge poses serious threat to the dominant power structures operating in American society that privileges Whites over all other racial groups" (p. 5). Diversity courses are a non-threatening way for social work programs to appear they are committed to diversity without requiring transformative pedagogical changes.

The Council on Social Work Education (2015) sets the standard within the accreditation competencies to "engage difference and diversity" (p. 7). Competency two in the accreditation standards expressly states, "social workers apply self-awareness and selfregulation to manage the influence of personal biases and values in working with diverse clients and constituencies" (CSWE, 2015, p. 7). This mandate by CSWE is a call to action to examine implicit bias within both our profession and within our education programs. Probing the implicit bias of social work students can be visualized as a foundational step for BSWEs to answer the call of guiding students to develop the necessary self-awareness and self-regulation to manage their personal bias while working with clients of diverse racial backgrounds. Implicit bias, Eberhardt (2019) argues, influences all people by acting 
as a "distorting lens" that has the power to sway our perceptions and ideas about race (p. 6). They further contend this bias is "not limited to one profession, one race, or one country" (Eberhardt, 2019, p. 7). Social work education has thus far been content with reinforcing bias by only celebrating race and focusing primarily on self instead of interrogating and challenging the faulty system that allows racist inequities and disparities to persist.

\section{Implications for Social Work}

Both the NASW and CSWE emphasize the importance of social workers and social work students increasing their knowledge of personal biases and values to mitigate the potential negative impact on clients. After roughly 30 years, in 1992 CSWE made diversity content a program accreditation requirement (Garcia \& Van Soest, 1997; Kohli et al., 2010). Regardless of the recent attention given to cultural competence within social work education, scholarship has called to question this foundational tenet of the profession. Despite the foundational legacy cultural competency holds in modern social work the profession is not above criticism. The current multiculturalism and cultural competency framework does not critique social systems and focuses on individual change rather than systems of oppression (Abrams \& Moio, 2009; Jeyasingham, 2012; Sakamoto, 2007; Varghese, 2016). According to Sakamoto (2007), cultural competency rarely critically analyzes Whiteness within social work. Scholars have argued Whiteness is the default standard for all others to be measured by (Applebaum, 2010; Davis, 2016; Delgado \& Stefancic, 1997, 2012; DiAngelo, 2018; Owen, 2007; Young \& Zubrzycki, 2011, Zembylas, 2015). Scholars assert that social work is built on a foundation of Whiteness; thus, cultural competency is implicitly bound to the principles of Whiteness (Abrams \& Moio, 2009; Sakamoto, 2007; Varghese, 2016).

The findings for this study have implications for faculty development and education. These participants portrayed ideologies and strategies that align with social justice theoretical foundations, however, none of them identified social justice pedagogy explicitly. Davis (2016) argues it seems unusual that Ph.D. level graduates "are not required to learn much about race at the Ph.D. level" although they will at some point be required to teach about it (p. 400). I would further argue that race and anti-racist education needs to be critically incorporated into the curriculum at all levels for two primary reasons. First, in social work education, CSWE does not require any additional training, scholarship, or education specific to racism before they can teach. Yet in line with the research, participants in this study shared that a lack of faculty readiness, their own and colleagues, to engage in critical conversations about race is one barrier faculty must overcome to effectively teach about racism.

While the majority of the social work faculty hold Ph.D.s (67.6\%), having a Ph.D. is not required to teach in social work programs (CSWE, 2017). Therefore, as Davis (2016) noted that those in Ph.D. programs will have to teach content on race, I assert so will those social work educators who do not hold Ph.D.s. Faculty at the master's level must also be prepared to teach content on race with the foundation for understanding the impact of race and racism beginning in the undergraduate program. Centering and requiring content on 
race should be critically and explicitly taught throughout all levels in social work education. This may contribute to both the foundation of future educators and to help develop students' knowledge and skills to participate in a broader analysis and collaboration to address race and racism in social work practice and policy.

Second, the need for current social work educators to have access to professional development centered on strategies for teaching anti-racism in their professional networks is evident. Social work educators are not trained in pedagogy nor are they typically socialized into classroom teaching. Social work scholars have failed to intently examine the knowledge, skills, or disposition of social work faculty who teach about race and racism and the impact on their teaching practice. This creates tension within social work preparation programs to provide recommendations for evidence-based teaching practices as the focus of social work programs is to develop practitioners. This study displayed that although faculty may be committed to teaching anti-racist content, they lack the formal training, curriculum knowledge, experience with pedagogical strategies, and professional development support to fully engage in critical anti-racist content in social work programs. Social work programs (and the institutions that house them) could develop required professional development workshops for both full and part-time faculty, irrespective of their tenure status, that addresses racism and provides strategies for anti-racist teaching. Additionally, CSWE could revise its teaching requirements to include documented antiracist teaching professional development. To help fuel this effort CSWE could work with experts, as well as NASW, to create training opportunities and make them available online and at the Annual Program Meeting (APM).

Lastly, there is a need to support the growth of practitioners who want to become educators and social work education leaders who understand social justice pedagogical strategies beyond professional development. There is a copious amount of empirical work, articles, and essays detailing the racial and gendered bias experienced in higher education, such as racial microaggressions encountered by faculty of color from students and colleagues (Edmonds- Cady and Wingfield, 2017; Love, 2019; Richards, 2019; Smith et al., 2017), and bias embedded in students' evaluations of teaching (Edmonds-Cady \& Wingfield, 2017; Richards, 2019). Richards (2019) further illustrates how faculty assessments have been weaponized against faculty who teach about racial injustice. Utilizing a color-blind racism frame she outlined how institutions can both claim to value diversity and inclusivity, while simultaneously contributing to the marginalization of some of its faculty.

Richards (2019) advocates for the institutionalization of race-and gender-conscious systems of evaluation, mentorship, and support. Institutions that proactively create antiracist and anti-sexist systems of support that clearly outline tenure expectations offer robust professional development provided by those with expert knowledge, and centers mentorship that is explicitly anti-racist and anti-sexist can help develop a set of best practices. I assert that social work programs can lead the way by enacting these ideas at the program level. Furthermore, CSWE can support this work by incorporating these steps into the revised accreditation standards as a way to offer social work programs support in the implementation of these race-conscious pedagogical strategies. 


\section{Recommendations}

Racism has a complicated history in the United States. It is a complex set of events that encroaches on our daily lives. Therefore, the role of race and racism should not be regulated to one course within social work education or only infused throughout the curriculum. A comprehensive approach that incorporates both a course focused on race and racism and antiracist content scaffolded throughout the curriculum should be implemented. The Council on Social Work Education (CSWE) should consider making this scaffolded approach part of the accreditation process.

The inclusion of specific strategies to build faculty's comfort and skills around facilitating learning around race and racism should be incorporated into graduate-level social work programs. This is my second recommendation. CRT combined with social justice pedagogy offers social work education the opportunity to restructure the curriculum to center race and its intersectionality with all forms of oppression. Racism continues to be America's original sin. Some social work educators are employing social justice strategies in the learning environment but these participants highlighted the haphazard way educators may become familiar with social justice strategies. Participants reflected on their own college experiences with race and racism and revealed they desired a more meaningful experience. CRT and social justice pedagogy can provide a foundation and a framework to engage in addressing the challenge of critical analysis of race and racism within social work curriculum.

My final recommendation is related to the professional development opportunities for faculty who teach content on race and racism. Due to the unique skills required to effectively facilitate learning around anti-racism additional opportunities should be presented through CSWE, the Association of Baccalaureate Social Work Program Directors (BPD), NASW, and other organizations to provide training and professional development. Therefore providing both full-time and contingent faculty more opportunity to increase their pedagogical skills around anti-racism and anti-blackness. This may also further foster more critical research about race and antiracist praxis within social work scholarship to focus on ways to impact social policy and dismantle racist systems.

\section{Conclusion}

Racial disparities within the United States continue to be pervasive and persistent. I conducted this study during a time of the resegregation of public schools (Hannah-Jones, 2014); a mortality rate for Black infants being twice the rate of White infants (Mathews et al., 2015); increasing White nationalist activity (SPLC, n.d.); Native American young adults having the highest suicide rates of all other groups (Jiang et al., 2015); and 32\% of Black men killed by police in the United States in 2015 were unarmed (Swaine et al., 2015). With the prevalence of social media, the persistent White supremacy embedded into the very marrow of the United States has been exposed through the onslaught of racist conflicts, crimes, and counter-protests that have occurred in recent years. As a true "boots on the ground" profession, social work is uniquely positioned to ameliorate racial bias, racial injustice, and racial discrimination with its engagement of virtually every social 
problem. The findings in this study are significant for social work education and practice by providing a more nuanced examination of undergraduate social work educators who encourage students to engage in anti-racist social work praxis.

\section{References}

Abrams, L. S., \& Gibson, P. (2007). Teaching notes: Reframing multicultural education: teaching White privilege in the social work curriculum. Journal of Social Work Education, 43(1), 147-160. https://doi.org/10.5175/jswe.2007.200500529

Abrams, L. S., \& Moio, J. A. (2009). Critical race theory and the cultural competence dilemma in social work education. Journal of Social Work Education, 45(2), 245261. https://doi.org/10.5175/jswe.2009.200700109

Adams, M., \& Zuniga, X. (2016). Getting started: Core concepts for social justice education. In M. Adams \& L. A. Bell (Eds.), Teaching for diversity and social justice (pp. 95-130). Taylor \& Francis Group. https://doi.org/10.4324/9781315775852-11

Amankwaa, L. (2016). Creating protocols for trustworthiness in qualitative research. Journal of Cultural Diversity, 23(3), 121-127.

Applebaum, B. (2010). Race, critical race theory and Whiteness. In P. Peterson, E. Barker, \& B. McGraw (Eds.), International encyclopedia of education (pp. 36-43). Elsevier LTD. https://doi.org/10.1016/B978-0-08-044894-7.00541-8

Bell, D. A. (1980). Brown v. Board of Education and the interest convergence dilemma. Harvard Law Review, 93, 518-533. https://doi.org/10.2307/1340546

Bonilla-Silva, E. (2018). Racism without racists: Color-blind racism and the persistence of racial inequality in America. Rowman \& Littlefield.

Brew, A., \& Mantai, L. (2017). Academics' perceptions of the challenges and barriers to implementing research-based experiences for undergraduates. Teaching in Higher Education, 22(5), 551-568. https://doi.org/10.1080/13562517.2016.1273216

Campbell, E. (2014). Using critical race theory to measure "racial competency" among social workers. Journal of Sociology and Social Work, 2(2), 1-14. https://doi.org/10.15640/jssw.v2n2a5

Constance-Huggins, M. (2012). Critical race theory in social work education: A framework for addressing racial disparities. Critical Social Work, 13(2), 2-16. https://doi.org/10.22329/csw.v13i2.5861

Constance-Huggins, M. (2018). Intersection of race, gender, and nationality in teaching about race and racism. Reflective Practice, 19(1),81-88. https://doi.org/10.1080/14623943.2017.1361918

Council on Social Work Education [CSWE]. (2008). Educational Policy and Accreditation Standards. https://www.cswe.org/getattachment/Accreditation/Standards-and-Policies/2008EPAS/2008EDUCATIONALPOLICYANDACCREDITATIONSTANDARDS(EPA S)-08-24-2012.pdf.aspx 
CSWE. (2015). Educational Policy and Accreditation Standards. https://www.cswe.org/getattachment/Accreditation/Accreditation-Process/2015EPAS/2015EPAS_Web_FINAL.pdf.aspx

CSWE. (2017). 2016 Annual Statistics on Social Work Education in the United States. Author. https://www.cswe.org/CMSPages/GetFile.aspx?guid=6e8bc9e7-ebd6-4288$\underline{\text { bc7a-d2d427d68480 }}$

CSWE. (2020). 2019 Annual statistics on social work education in the United States. Author. https://www.cswe.org/getattachment/Research-Statistics/2019-AnnualStatistics-on-Social-Work-Education-in-the-United-States-Final-(1).pdf.aspx

Crenshaw, K. (1995). Race reform, and retrenchment: Transformation and legitimation in antidiscrimination law. In N. Gotanda, G. Peller, \& K. Thomas (Eds), Critical race theory: The key writings that formed the movement (pp. 103-122). The New Press. https://doi.org/10.1515/9780691186429-023

Creswell, J. W. (2013). Qualitative inquiry \& research design: Choosing among five approaches. Sage.

Davis, L. E. (2016). Race: America's grand challenge. Journal of the Society for Social Work and Research, 7(2), 395-403. https://www.journals.uchicago.edu/doi/pdf/10.1086/686296

Deepak, A. C., Rountree, M. A., \& Scott, J. (2015). Delivering diversity and social justice in social work education: the power of context. Journal of Progressive Human Services, 26(2), 107-125. https://doi.org/10.1080/10428232.2015.1017909

Delgado, R., \& Stefancic, J. (Eds.). (1997). Critical White studies. Temple University Press.

Delgado, R., \& Stefancic, J. (2012). Critical race theory: An introduction (2nd ed.). New York University Press.

DiAngelo, R. J. (2018). White fragility : why it's so hard for White people to talk about racism. Beacon Press.

Eberhardt, J. L. (2019). Biased: Uncovering the Hidden Prejudice That Shapes What We See, Think, and Do. Penguin Group USA.

Edmonds-Cady, C., \& Wingfield, T. T, (2017). Social workers: Agents of change or agents of oppression?. Social Work Education, 36(4), 430-442. http://dx.doi.org/10.1080/02615479.2017.1291802

Essed, P. (1991). Understanding everyday racism: An interdisciplinary theory. Sage

Garcia, B., \& Van Soest, D. (1997). Changing perceptions of diversity and oppression: MSW students discuss the effects of a required course. Journal of Social Work Education, 33(1), 119-129. https://doi.org/10.1080/10437797.1997.10778857

Grand Challenges for Social Work. (2021). About. https://grandchallengesforsocialwork.org/ 
Hannah-Jones, N. (2014, May). Segregation now. The Atlantic. http://www.theatlantic.com/magazine/archive/2014/05/segregation-now/359813/

Harding, S. (1993). Whose science? Whose knowledge?: Thinking from women's lives. Cornell University Press.

Holland, A. E. (2015). The lived experience of teaching about race in cultural nursing education. Journal of Transcultural Nursing, 26(1), 92-100. https://doi.org/10.1177/1043659614523995

Holstein, J. A., \& Gubrium, J. F. (1995). The active interview. Sage.

Jay, M. (2003). Critical race theory, multicultural education, and the hidden curriculum of hegemony. Multicultural Perspectives, 5(4), 3-9. https://doi.org/10.1207/s15327892mcp0504_2

Jeffery, D. (2005). What good is anti-racist social work if you can't master it?" Exploring a paradox in social work education. Race Ethnicity and Education, 8(4), 409-425 https://doi:10.1080/13613320500324011

Jeyasingham, D. (2012). White noise: A critical evaluation of social work education's engagement with whiteness studies. British Journal of Social Work, 42(4), 669-686. https://doi.org/10.1093/bjsw/bcr110

Jiang, C., Mitran, A., Miniño, A., \& Ni, H. (2015). Racial and gender disparities in suicide among young adults aged 18-24: United States, 2009-2013. Health-E Stats series. National Center for Health Statistics. https://www.cdc.gov/nchs/data/hestat/suicide/racial and gender 2009 2013.pdf

Kohli, H. K., Huber, R., \& Faul, A. C. (2010). Historical and theoretical development of culturally competent social work practice. Journal of Teaching in Social Work, 30(3), 252-271. https://doi.org/10.1080/08841233.2010.499091

Kolivoski, K. M., Weaver, A., \& Constance-Huggins, M. (2014). Critical race theory: Opportunities for application in social work practice and policy. Families in Society, 95(4), 269-276. https://doi.org/10.1606/1044-3894.2014.95.36

Lincoln, Y. S., \& Guba, E. G. (1985). Naturalistic inquiry. Sage.

Love, B. L. (2019). We want to do more than survive. Abolitionist Teaching and the pursuit of educational freedom. Beacon Press.

Mathews, T. J., MacDorman, M. F., \& Thoma, M. E. (2015). Infant mortality statistics from the 2013 period linked birth/infant death data set. National Center for Health Division of Vital Statistics. National Vital Statistics Reports, 64(9), 1-30. http://www.cdc.gov/nchs/data/nvsr/nvsr64/nvsr64 09.pdf

Matias, C. E., \& Mackey, J. (2015). Breakin' down whiteness in antiracist teaching: Introducing critical whiteness pedagogy. The Urban Review, 48(1), 32-50. https://doi.org/10.1007/s11256-015-0344-7 
Merriam, S. B. (2009). Qualitative research: A guide to design and implementation. Jossey-Bass.

NASW Social Work Policy Institute. (2014). Achieving racial equity: Calling the social work profession to action.

http://www.antiracistalliance.com/SWPIRacialEquityReport.pdf

Ortiz, L., \& Jani, J. (2010). Critical race theory: A Transformational model for teaching diversity. Journal of Social Work Education, 46(2), 175-193. https://doi.org/10.5175/jswe.2010.200900070

Owen, D. S. (2007). Towards a critical theory of whiteness. Philosophy \& Social Criticism, 33, 203-222. https://doi.org/10.1177/0191453707074139

Patton, L. D. (2016). Disrupting postsecondary prose: Toward a critical race theory of higher education. Urban Education, 51(3), 315-342. https://doi.org/10.1177/0042085915602542

Patton, M. Q. (2015). Qualitative research \& evaluation methods: Integrating theory and practice. Sage.

Pittman Chavella, T. (2010). Exploring how African American faculty cope with classroom racial stressors. Journal of Negro Education, 79(1), 66-78.

Pittman Chavella, T. (2012). Racial microaggressions: The narratives of African American faculty at a predominantly White university. Journal of Negro Education 81(1), 82-92. https://doi.org/10.7709/jnegroeducation.81.1.0082

Rahill, G. J., Joshi, M., Lucio, R., Bristol, B., Dionne, A., \& Hamilton, A. (2016). Assessing the development of cultural proficiency among upper-level social work students. Journal of Social Work Education, 52(2), 198-213. https://doi.org/10.1080/10437797.2016.1152134

Richards, B. N. (2019). Faculty assessments as tools of oppression: A Black woman's reflections on (colorblind) racism in the Academy. In W. Carson Byrd, R. J. BrunnBevel, \& S. M. Ovink (Eds.), Intersectionality and higher education: Identity and inequality on college campuses (pp. 136-152). Rutgers University Press. https://doi.org/10.36019/9780813597706-009

Sakamoto, I. (2007). An anti-oppressive approach to cultural competence. Canadian Social Work Review, 24(1), 105-118.

Saldaña, J. (2015). The coding manual for qualitative researchers. Sage.

Shavers, M. C., \& Moore, J. L. (2014). Black female voices: Self-presentation strategies in doctoral programs at predominately White institutions. Journal of College Student Development, 55(4), 391-407. https://doi.org/10.1353/csd.2014.0040

Smith, L., Kashubeck-West, S., Payton, G., \& Adams, E. (2017). White professors teaching about racism: Challenges and rewards. The Counseling Psychologist, 45(5), 651-668. https://doi.org/10.1177/0011000017717705 
Smith-Maddox, R. \& Solórzano, D. (2002). Using critical race theory: Paulo Freire's problem-posing methods, and case study research to confront race and racism in education. Qualitative Inquiry, 8(1), 66-84. https://doi.org/10.1177/107780040200800105

Southern Poverty Law Center [SPLC]. (2018). Hate map. https://www.splcenter.org/hatemap

SPLC. (n.d.). Home. https://www.splcenter.org/

Strauss, A., \& Corbin, J. (1998). Basics of qualitative research: Grounded theory procedures and techniques (2nd ed.). Sage. https://doi.org/10.4135/9781452230153

Swaine, J., Laughland, O., \& Lartey, J. (2015, June 1). Black Americans killed by police twice as likely to be unarmed as White people. The Guardian.

https://www.theguardian.com/us-news/2015/jun/01/black-americans-killed-bypolice-analysis

Varghese, R. (2016). Teaching to transform? Addressing race and racism in the teaching of clinical social work practice. Journal of Social Work Education, 52(sup1), S134S147. https://doi.org/10.1080/10437797.2016.1174646

Young, S., \& Zubrzycki, J. (2011). Educating Australian social workers in the postApology era: The potential offered by a 'Whiteness' lens. Journal of Social work, 11(2), 159-173. https://doi.org/10.1177/1468017310386849

Zembylas, M. (2015). 'Pedagogy of discomfort' and its ethical implications: the tensions of ethical violence in social justice education. Ethics and Education, 10(2), 163-174. https://doi.org/10.1080/17449642.2015.1039274

Author note: Address correspondence to Ebony Perez, Department of Undergraduate Social Work, Saint Leo University, St. Leo, FL 33574. Email: ebony.perez@saintleo.edu 